\title{
Mesozooplankton grazing in the Southern California Bight. II. Grazing impact and particulate flux
}

\author{
M. R. Landry ${ }^{1}$, C. J. Lorenzen ${ }^{2, *}$, W. K. Peterson ${ }^{2}$ \\ ${ }^{1}$ Department of Oceanography, University of Hawaii at Manoa, 1000 Pope Road, Honolulu, Hawaii 96822, USA \\ ${ }^{2}$ School of Oceanography, University of Washington, Seattle, Washington 98195 , USA
}

\begin{abstract}
Mesozooplankton grazing on phytoplankton, as inferred from gut pigment contents and gut evacuation rates, was studied in relation to primary production and particulate export flux on 6 cruises in the Santa Monica Basin, California, USA. Gut evacuation rates did not vary significantly among different taxa or size classes examined and were consistent with extrapolations of published temperature relationships. Shipboard incubations with cultured phytoplankton and net-collected zooplankton indicated a seasonal difference in the extent to which gut passage converts chlorophyll to non-fluorescent by-products. In autumn experiments, only about $5 \%$ of ingested chlorophyll could not be recovered as phaeopigment. In winter-spring experiments, approximately $70 \%$ of ingested chlorophyll (chl) was destroyed. In contrast, other indices of pigment destruction, the ingestion rates of a dominant copepod species and the ratio of water-column phaeopigment:silica fluxes, did not reveal a significant gut passage effect during winter-spring cruises. Mesozooplankton community grazing impact varied from 1.7 to $7.3 \mathrm{mg} \mathrm{chl} \mathrm{m} \mathrm{m}^{-2} \mathrm{~d}^{-1}$, with higher grazing during the winter-spring period

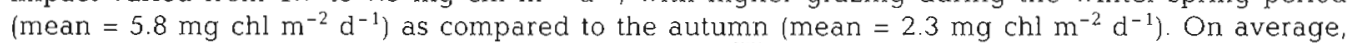
mesozooplankton grazing accounted for a loss of $11.7 \%$ of chlorophyll standing stock $\mathrm{d}^{-1}$ with a 6 cruise range of 6 to $18 \% \mathrm{~d}^{-1}$ Mesozooplankton grazing on phytoplankton accounted for 29 to $44 \%$ (mean $=39 \%$ ) of measured primary production for the winter-spring cruises, but only 16 to $24 \%$ (mean $=19 \%$ ) of production in the autumn. From measured phaeopigment fluxes into sediment traps below the euphotic zone, only $27.5 \%$ (range 23 to $32 \%$ ) of this grazing on phytoplankton could be accounted for as export flux. Thus, in terms of contribution to particulate flux or remineralization, most mesozooplankton grazing in the Santa Monica Basin was functionally equivalent to that of microzooplankton. Direct grazing on phytoplankton contributed 15 to $38 \%$ of carbon flux into sediment traps during winter-spring and 8 to $13 \%$ during autumn. Nonetheless, if feeding on nonpigmented prey is considered from the available information on carbon:phaeopigment ratios of fresh fecal pellets, over $70 \%$ of the carbon flux to traps could have a mesozooplankton grazing origin.
\end{abstract}

KEY WORDS: Zooplankton grazing · Chlorophyll - Carbon flux · Gut evacuation - Gut fluorescence · Sediment trap - Particulate flux

\section{INTRODUCTION}

Recent models of pelagic marine food webs, including those that guided the development of international Global Ocean Flux Studies, distinguish among the roles of zooplankton in particle flux largely on the basis of body size (e.g. Frost 1984, Pace et al. 1984, Fasham 1985, Michaels \& Silver 1988, Peinert et al. 1989). Protozoans and small animals which pass

'Died 21 November 1988; R.I.P. through fine plankton nets are assumed to contribute little to particle flux because their small fecal debris sink slowly and are consequently remineralized within the euphotic zone. In contrast, larger pelagic animals contribute disproportionately to flux, relative to their grazing impact, by virtue of the rapid sinking rates of their large feces and pellets (Paffenhöfer \& Knowles 1979, Small et al. 1979, Hofmann et al. 1981, Komar et al. 1981, Emerson \& Roff 1987). The partitioning of primary production between micro- and macroconsumers is an important conceptual link between production processes in the upper water column and 
export flux to depth. Gross patterns in new production, measured as the ratios of nitrate to total dissolved inorganic nitrogen (DIN) uptake rates or carbon flux to ${ }^{14} \mathrm{C}$ primary production (Eppley \& Peterson 1979, Welschmeyer \& Lorenzen 1985), appear to be consistent with interregional differences in the size structure of primary consumers (Michaels \& Silver 1988, Aksnes \& Wassmann 1993). However, details of the underlying relationships are only beginning to be explored in different marine ecosystems (e.g. Morales et al. 1991, 1993, Bautista \& Harris 1992, Dam et al. 1993, Roman et al. 1993). The present paper is an attempt to define relationships among primary production, mesozooplankton grazing on phytoplankton, and carbon and pigment export flux in the Santa Monica Basin region off Southern California, USA.

\section{MATERIALS AND METHODS}

Grazing rate estimates. Mesozooplankton grazing rates on phytoplankton were estimated by applying measurements of gut clearance rate to the gut pigment contents of Landry et al. (1994, this issue). Zooplankton for gut clearance experiments were collected during nighttime tows in the upper $50 \mathrm{~m}$ of the water column with a $0.5 \mathrm{~m}, 202 \mu \mathrm{m}$ mesh plankton net. Large gelatinous animals were removed from the net codend, if present, to avoid entangling other zooplankton in mucus. The remaining organisms were gently poured into 2 to $4 \mathrm{l}$ containers filled with GF/F glass-fiber filtered seawater. Residual phytoplankton was removed in several cycles of alternately concentrating (removing water through $202 \mu \mathrm{m}$ mesh) and diluting with filtered water. On some occasions, the rinsed zooplankton were used immediately in gut clearance experiments. More generally, experimental animals were first allowed to void their guts in filtered water for 1 to $2 \mathrm{~h}$, then fed on a suspension of cultured Thalassiosira weissflogii and Isochrysis galbana for 3 to $4 \mathrm{~h}$.

Following feeding, the zooplankton were separated from their food and fecal debris by successive cycles of concentration and dilution with filtered water. Random subsamples of the organisms were removed every $5 \mathrm{~min}$ for $45 \mathrm{~min}$, concentrated on $202 \mu \mathrm{m}$ Nitex screening, and flash frozen. Later, generally within a few hours of the end of the experiment, the samples were thawed and sorted into taxonomic groups for analysis of chlorophyll a (chl a) and phaeopigment by fluorescence (Holm-Hansen et al. 1965). The resulting pigment concentrations were corrected for the background fluorescence of zooplankton starved in filtered water for $24 \mathrm{~h}$.

The rate of gut clearance was computed from the time-series measurements of gut fluorescence assum- ing a constant exponential decline (Mackas \& Bohrer 1976, Kiørboe et al. 1982). Ingestion rates (I) of zooplankton taxa were subsequently calculated from gut clearance rates ( $r$ ) and gut pigment contents (GPC) as $I=r \times \mathrm{GPC}$.

Chlorophyll degradation. The effect of zooplankton feeding on the degradation of chl a to nonfluorescent residues was determined in shipboard experiments conducted in October 1986, April and October 1987, and February 1988. Mixed assemblages of zooplankton were collected from the euphotic zone and preconditioned in filtered seawater as described above. After they had cleared their stomach contents, they were concentrated, thoroughly rinsed in fresh filtered seawater, and placed in 21 polycarbonate bottles containing filtered water and mixtures of darkadapted cultures of Thalassiosira weissflogii and Isochrysis galbana. Similarly prepared bottles without zooplankton served as controls to account for nongrazing-related changes in pigment concentrations. Duplicate subsamples were drawn from experimental and control bottles for initial pigment analyses. The bottles were then double wrapped in aluminum foil and incubated in the dark for 6 to $8 \mathrm{~h}$. At the end of the incubation, the contents of the bottles were vigorously mixed and subsampled in triplicate for final pigment concentrations.

Pigment samples were concentrated on Whatman GF/F glass-fiber filters and extracted in $90 \%$ acetone with sonication ( $7 \mathrm{~min}$, Megason Ultrasonicator, $300 \mathrm{~W}$ ). $\mathrm{Chl} a$ and phaeopigment concentrations were determined fluorometrically (Holm-Hansen et al. 1965). No correction factor was applied in converting phaeopigment concentrations to $\mathrm{chl} a$ equivalents (Baars \& Helling 1985, Conover et al. 1986). The conversion efficiency of chl a to phaeopigments by mesozooplankton grazing was computed from the ratio of phaeopigment increase to chl a decrease in the experimental bottles.

Particulate flux. Sediment traps were deployed on 6 cruises from October 1985 to February 1988 to measure the rate of loss of particulate organic matter from the euphotic zone. Except for the last 2 cruises, we used the small cylindrical traps described by Welschmeyer \& Lorenzen (1985). These were PVC (polyvinyl chloride) cylinders with a mouth area of $41 \mathrm{~cm}^{2}$, an aspect (height: width) ratio of $3: 1$, and a volume of 0.9 I. Prior to deployment, the traps were cleaned with ethanol, rinsed with freshwater, and filled with refrigerated filtered seawater and additional $\mathrm{NaCl}$ to establish a density gradient. The traps were hung individually on a wire attached to a surface float. Standard depths for the present study were $10 \mathrm{~m}$ intervals from 10 to $100 \mathrm{~m}, 125 \mathrm{~m}$, and $50 \mathrm{~m}$ intervals from 150 to $300 \mathrm{~m}$. The deployment interval for the free-drifting array was $24 \mathrm{~h}$ beginning before sunrise. A time- 
released messenger system closed the traps before recovery. In October 1987 and February 1988, we used traps (designed by $\mathrm{N}$. Welschmeyer) which were substantially identical to those used previously except for a greater aspect ratio (5:1) and trap volume (1.31). These traps were deployed in triplicate at $50 \mathrm{~m}$ depth intervals from 50 to $300 \mathrm{~m}$.

Following recovery of the array, zooplankton were removed from the trap material by a combination of screening and microscopical sorting. The trap contents were thoroughly mixed, and triplicate samples were GF/F filtered for pigment analyses. Chlorophyll $a$ and phaeopigment concentrations were determined fluorometrically after sonication and 90\% acetone extraction. Duplicate subsamples of the trap material were filtered onto precombusted $0.45 \mu \mathrm{m}$ silver filters for analyses of particulate carbon and nitrogen. These analyses were made with a Carlo Erba Model 1106 Elemental Analyzer using acetanilide as a standard.

On the April 1987 and February 1988 cruises and on subsequent cruises in January and July 1990 (Landry et al. 1992), we determined the concentration of particulate biogenic silica in sediment traps and in the water column (10 $\mathrm{m}$ increments to $100 \mathrm{~m}$ depth). Samples were filtered onto $25 \mathrm{~mm}, 0.4 \mu \mathrm{m}$ Nuclepore filters or $0.45 \mathrm{\mu m}$ Millipore methylcellulose filters (beginning April 1987). The filters were folded and stored frozen in clean polystyrene test tubes until analysis. Particulate biogenic silica was solubilized according to the hot $\mathrm{NaOH}$ digestion method of Paasche (1973), as modified by Furnas et al. (1976). The resulting concentrations of dissolved silicate were determined against prepared standards using a Technicon autoanalyzer.

Flux rates ( $\mathrm{mg} \mathrm{m}^{-2} \mathrm{~d}^{-1}$ ) of phytoplankton pigments, particulate carbon, and biogenic silica were computed from measured concentrations in the traps by the equation:

$$
\text { Flux }=\frac{[C] \times V}{A \times t}
$$

where $[C]$ is concentration ( $\mathrm{mg} \mathrm{l}^{-1}$ ), $V$ is trap volume (1), $A$ is the cross-sectional area of the trap mouth $\left(\mathrm{m}^{2}\right)$, and $t$ is the duration of deployment (d).

\section{RESULTS}

\section{Gut clearance rates}

The results of 22 determinations of gut clearance rates for mesozooplankton from the Santa Monica Basin are presented in Table 1. Although the zooplankton were prefed cultured algae before most

Table 1. Gut clearance rates of mesozooplankton from the Santa Monica Basin, California, USA. All animals were collected at night from 0 to $70 \mathrm{~m}$ depth. 'Field' estimates of gut pigment content (ng ind. ${ }^{-1}$ ) are for specimens frozen immediately from the net codend; ' $t_{0}$ ' estimates are from the start of the gut evacuation experiment which generally followed a period of incubation with cultured phytoplankton (but not for experiments marked with '). n: number of sample points in the regression analysis. Developmental stage: $F$, female; $\mathrm{C} 1-5$, copepodid stages 1 to 5 ; cop., copepodids; juv, juveniles

\begin{tabular}{|c|c|c|c|c|c|c|}
\hline Species, stage & Date & \multicolumn{2}{|c|}{ Gut pigment content } & $\begin{array}{c}\text { Rate } \\
\left(\mathrm{min}^{-1}\right)\end{array}$ & $\mathrm{R}^{2}$ & $\mathrm{n}$ \\
\hline \multirow[t]{5}{*}{ Calanus pacificus, F } & May 1986 & 4.28 & $4.03^{\circ}$ & -0.050 & 0.66 & 7 \\
\hline & May 1986 & 4.28 & $4.33^{\circ}$ & -0.082 & 0.85 & 7 \\
\hline & Oct 1986 & 2.10 & 0.93 & -0.039 & 0.88 & 6 \\
\hline & Apr 1987 & 2.13 & 5.30 & -0.057 & 0.83 & 9 \\
\hline & Feb 1988 & 6.42 & 7.71 & -0.109 & 0.84 & 8 \\
\hline C5 & Apr 1987 & 1.23 & 1.61 & -0.036 & 0.65 & 9 \\
\hline $\mathrm{C} 4$ & Apr 1987 & 0.74 & 0.93 & -0.065 & 0.94 & 9 \\
\hline $\mathrm{C} 2-\mathrm{C} 3$ & Apr 1987 & 0.27 & 0.36 & -0.069 & 0.93 & 8 \\
\hline $\mathrm{C} 1-\mathrm{C} 2$ & Apr 1987 & 0.28 & $0.061^{\circ}$ & -0.030 & 0.60 & 8 \\
\hline Nauplii & Apr 1987 & 0.13 & $0.061^{\circ}$ & -0.074 & 0.94 & 4 \\
\hline Clausocalanus arcuicornis, $\mathrm{F}$ & Oct 1986 & 0.46 & 0.30 & -0.088 & 0.86 & 9 \\
\hline \multirow[t]{3}{*}{ Clausocalanus pergens, $\mathrm{F}$} & Oct 1986 & 0.21 & 0.99 & -0.039 & 0.48 & 9 \\
\hline & Apr 1987 & 0.43 & $0.069^{\circ}$ & -0.048 & 0.65 & 8 \\
\hline & Feb 1988 & 0.26 & 0.12 & -0.042 & 0.46 & 7 \\
\hline \multirow[t]{2}{*}{ Clausocalanus spp., cop. } & Oct 1986 & 0.22 & 0.47 & -0.078 & 0.88 & 7 \\
\hline & Oct 1986 & 0.21 & 0.37 & -0.054 & 0.81 & 7 \\
\hline \multirow[t]{2}{*}{ Mixed small calanoid cop. } & Apr 1987 & 0.27 & 0.46 & -0.063 & 0.79 & 9 \\
\hline & Apr 1987 & 0.13 & $0.047^{\circ}$ & -0.047 & 0.34 & 8 \\
\hline Euphausia pacifica, juv. & Oct 1986 & 1.40 & 0.89 & -0.087 & 0.33 & 8 \\
\hline Metridia lucens, $\mathrm{F}$ & Oct 1986 & 2.24 & 1.57 & -0.049 & 0.89 & 5 \\
\hline Oncaea spp. & Oct 1986 & 0.33 & 0.15 & -0.064 & 0.45 & 7 \\
\hline Pleuromamma borealis, F & Feb 1988 & 3.20 & 2.90 & -0.011 & 0.13 & 7 \\
\hline
\end{tabular}


experiments, the initial levels of gut pigment were generally close to the pigment contents of freshly captured zooplankton from the field. The largest difference between 'field' and ' $t_{0}$ ' pigment estimates occurred during experiments on 13 April 1987, when field-collected zooplankton were not prefed prior to the gut clearance incubation and lost most of their gut contents during experimental setup. However, the rate estimates from these experiments were not markedly different from the results for prefed zooplankton.

Although the correlation coefficients for individual experiments were usually high, rate estimates were quite variable from one experiment to the next. For Calanus pacificus and Clausocalanus spp., for example, standard deviations were, respectively, 39 and $34 \%$ of mean values. The overall mean and standard deviation, $0.058 \pm 0.022 \mathrm{~min}^{-1}$, gave a similar coefficient of variation. Despite this variability, there was surprisingly good agreement in the mean estimates of gut clearance rates for different groupings of the data. For example, there was no apparent effect of animal size in comparing all Calanus pacificus (mean $0.061 \mathrm{~min}^{-1}, \mathrm{SD}=0.024 \mathrm{~min}^{-1}, \mathrm{n}=10$ ) and Clausocalanus spp. $\left(0.058 \mathrm{~min}^{-1}, \mathrm{SD}=0.020 \mathrm{~min}^{-1}\right.$. $\mathrm{n}=6$ ) data or rate estimates for $\mathrm{C} 4$ to adult (0.053 $\left.\mathrm{min}^{-1}, \mathrm{SD}=0.015 \mathrm{~min}^{-1}, \mathrm{n}=3\right)$ and nauplii to C3 $\left(0.057 \mathrm{~min}^{-1}, \mathrm{SD}=0.024 \mathrm{~min}^{-1}, \mathrm{n}=3\right)$ stages of Calanus pacificus from April 1987. Likewise, marginally higher estimates of gut clearance rate occurred in the October 1.986 data $\left(0.062 \mathrm{~min}^{-1}, \mathrm{SD}=0.020, \mathrm{n}=8\right.$ ) as compared to February to May $\left(0.056 \mathrm{~min}^{-1}, \mathrm{SD}=\right.$ $0.024 \mathrm{~min}^{-1}, \mathrm{n}=14$ ).

Experimental temperatures in the present study were on the extreme high end of conditions for which Dam \& Peterson (1988) fit a general relationship between gut clearance estimates and temperature from the literature. Extrapolation of their linear relationship, $k\left(\mathrm{~min}^{-1}\right)=0.0117+0.001794 T$, yields an estimate of $0.0458 \mathrm{~min}^{-1}$ at $19^{\circ} \mathrm{C}$ that is a good deal lower than our observed rates. In contrast, the exponential relationship from Dam \& Peterson's (1988) data for Temora longicornis, $k\left(\mathrm{~min}^{-1}\right)=0.0121 \mathrm{e}^{0.0864 T}$, fits our results extremely well, predicting gut clearance rates of $0.062 \mathrm{~min}^{-1}$ at $19^{\circ} \mathrm{C}$ and $0.055 \mathrm{~min}^{-1}$ at $17.5^{\circ} \mathrm{C}$. Consequently, we used this latter model to adjust our observed rates from shipboard experiments to the mean temperature for the depth range of our zooplankton sampling, 0 to $70 \mathrm{~m}$. Since depth-averaged temperatures varied narrowly between 12.5 (May 1986) and $13^{\circ} \mathrm{C}$ (April 1987) for the winter-spring cruises, we used a mean temperature of $12.8^{\circ} \mathrm{C}$ and a gut clearance rate estimate of $0.037 \mathrm{~min}^{-1}$ for these cruises. The depth-averaged temperatures for the October cruises ranged from $15.0(1985)$ to $16.5^{\circ} \mathrm{C}$ (1986) with a mean of $15.9^{\circ} \mathrm{C}$. Accordingly, we used a mean estimate of $0.048 \mathrm{~min}^{-1}$ for gut clearance rate on the autumn cruises. Season-averaged gut clearance estimates were applied to gut pigment data for all mesozooplankton taxa (Tables 1 to 6 in Landry et al. 1994).

\section{Chlorophyll conversion to phaeopigments}

Based on direct measurements of phaeopigment recovery from grazed phytoplankton cultures (Table 2), there appeared to be a strong seasonal effect in the fraction of pigments destroyed during gut passage through the mesozooplankton. On average, $71 \%$ of chlorophyll was lost to nonfluorescent residues in the 6 experiments from late-winter and spring cruises. Phaeopigment recovery varied from 15 to $45 \%$ of grazed chlorophyll. In contrast, phaeopigment recovery for 5 October experiments ranged from 87 to $108 \%$, indicating that very little of the pigment was destroyed (mean $5.2 \%$ ) during the digestive process at this time of the year. Unnaturally high levels of chlorophyll were used in October 1986 experiments. Otherwise, initial chlorophyll concentrations were representative of levels in the field, although the total food availability was likely less than that in the field because we excluded detritus and nonpigmented prey. For April 1987 and February 1988 experiments, the trends were for decreasing phaeopigment recovery with increasing chlorophyll concentration. This was not the case for October 1987, or for all data combined.

Table 2. Seasonal differences in apparent pigment destruction by mixed mesozooplankton in the Santa Monica Basin. All shipboard incubations with field-collected animals incubated in the dark with cultured phytoplankton at initial concentration ' $\mathrm{Chl}_{0}$ ' 'Chl eaten'. \% of chlo consumed by the zooplankton assemblage in 4 to $5 \mathrm{~h}$. 'Ph recovery' phaeopigment increase $\left(\mu \mathrm{g} \mathrm{I}^{-1}\right) / \mathrm{chl}$ decrease ( $\left.\mu \mathrm{g} \mathrm{I}^{-1}\right)$

\begin{tabular}{|lccc|}
\hline Date & $\begin{array}{c}\mathrm{Chl}_{0} \\
\left(\mu \mathrm{g} \mathrm{chl} \mathrm{a}^{-1}\right)\end{array}$ & $\begin{array}{c}\text { Chl eaten } \\
(\%)\end{array}$ & Ph recovery \\
\hline $\begin{array}{l}\text { Winter-spring } \\
\text { 12 Apr 1.987 }\end{array}$ & 1.0 & 64 & 0.36 \\
& 2.6 & 77 & 0.33 \\
& 4.7 & 46 & 0.29 \\
10 Feb 1988 & 0.8 & 54 & 0.45 \\
& 2.5 & 59 & 0.17 \\
& 7.1 & 58 & 0.15 \\
Autumn & & & \\
17 Oct 1986 & 29.7 & 20 & 0.95 \\
18 Oct 1986 & 22.2 & 22 & 1.08 \\
11 Oct 1.987 & 0.6 & 62 & 0.91 \\
& 1.5 & 70 & 0.87 \\
& 2.7 & 70 & 0.93 \\
\hline
\end{tabular}




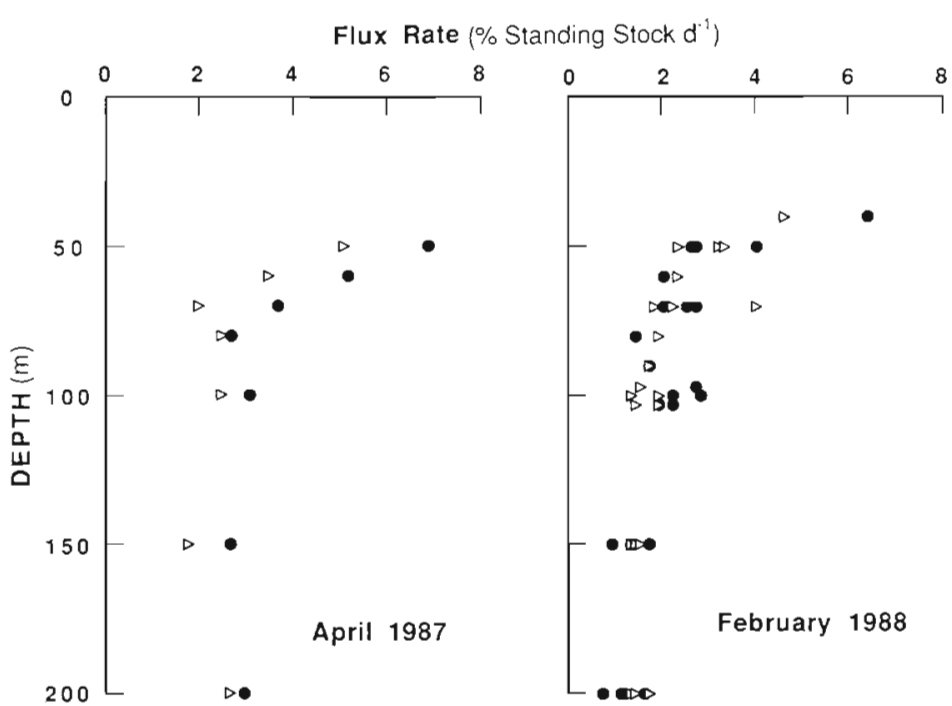

Fig. 1. Flux rates of phaeopigment $(\bullet)$ and particulate biogenic silica ( $\triangleright$ ) as measured by sediment traps at various depths between 40 and $200 \mathrm{~m}$ in the Santa Monica Basin, California, USA, in April 1987 and February 1988. Flux rates are presented as the percentages of depth-integrated standing stocks of chlorophyll a and biogenic silica, respectively, above the trap depth

From results of the pigment degradation experiments, we would conclude that gut pigment data for winter and spring cruises should be multiplied by approximately a factor of 3 to correct for pigment destruction, while gut pigment data from the autumn cruises would receive little or no correction. Two additional lines of evidence, however, lead to a different conclusion. First, if a large fraction of ingested chlorophyll was lost during gut passage, we would expect a substantial difference in the relative proportion of pigments in particle flux out of the euphotic zone relative to constituents that are more inert. In Fig. 1 we compare the flux rate of pigment and biogenic silica, as percentages of their respective standing stocks in the overlying water column during April 1987 and February 1988. Diatoms were a dominant component of the phytoplankton community during these cruises; therefore, they probably represented the main sources of both chlorophyll and silica in the euphotic zone. For both cruises, the profiles for phaeopigment and silica fluxes were similar throughout the upper $200 \mathrm{~m}$. For both constituents, about 2 to $3 \%$ of standing stock exited the base of the euphotic zone each day indicating that pigment was not destroyed significantly relative to silica. In fact, where there are slight differ- ences, it appears that the relative export flux of phaeopigment was higher. We also found comparable ratios of phaeopigment and silica fluxes on a subsequent cruise in January 1990 (water column $\Sigma$ Si: $\sum$ chl $=53.2$; flux ratio $\mathrm{Si}: \mathrm{Ph}=48.7, \mathrm{SD}=5.1, \mathrm{n}=11$ ) although silica was somewhat enriched in trap material in July 1990 (water-column $\Sigma \mathrm{Si}: \sum \mathrm{chl}=$ 29.2; flux ratio $\mathrm{Si}: \mathrm{Ph}=40.4, \mathrm{SD}=2.5, \mathrm{n}=8$ ). Water column silica concentrations were not measured on any of the October cruises, but the July 1990 results were from a period in which temperature and pigment profiles were similar to autumn.

Second, if a large fraction of ingested chlorophyll was degraded during the winterspring cruises, but not in autumn, we would expect that uncorrected feeding rate inferences from gut pigment data would, for a given taxa, show pronounced and unrealistic seasonal patterns. We use females of the copepod Calanus pacificus for this comparison because their feeding capabilities are well known from laboratory investigations, their gut pigment contents were quantified on all cruises, and they were particularly abundant and dominant grazers of phytoplankton during the winterspring cruises when pigment destruction was observed experimentally. Clearance rate estimates for C. pacificus females do not show a pronounced seasonal trend (Table 3). The nighttime rate estimate was low for May 1986, but this was during a period of very high food abundance and comparable day-night feeding rates, as opposed to other cruises for which gut pigment varied significantly on a diel cycle (Landry et al. 1994).

Table 3. Seasonal comparison of estimated clearance and ingestion rates for female Calanus pacificus based on gut pigment contents uncorrected for pigment destruction. Gut pigment estimates are mean nighttime values from Landry et al. (1994). Clearance rates $(F)$ are calculated from gut pigment estimates and gut clearance rates of $2.22 \mathrm{~h}^{-1}\left(0.037 \mathrm{~min}^{-1}\right)$ for winter and spring cruises and $2.88 \mathrm{~h}^{-1}\left(0.048 \mathrm{~min}^{-1}\right)$ for October cruises. Estimates of ingestion rates for phytoplankton carbon (I) are derived from clearance rates, mean water-column pigment concentrations [Chl], and an assumed C:chl ratio of 50

\begin{tabular}{|c|c|c|c|c|}
\hline Cruise & $\begin{array}{l}\text { Gut pigment } \\
\left.\text { (ml equ. ind.- }{ }^{-1}\right)\end{array}$ & $\begin{array}{c}F \\
\left(\mathrm{ml} \text { ind. }{ }^{-1} \mathrm{~h}^{-1}\right)\end{array}$ & $\begin{array}{c}{[\mathrm{Chl}]} \\
\left(\mu \mathrm{g} \mathrm{chl} \mathrm{1^{-1 }}\right)\end{array}$ & $\begin{array}{c}I \\
\left(\mu \mathrm{g} \mathrm{C} \text { ind } .^{-1} \mathrm{~h}^{-1}\right)\end{array}$ \\
\hline \multicolumn{5}{|c|}{ Winter-spring } \\
\hline Feb 1988 & 7.68 & 17.0 & 0.726 & 0.62 \\
\hline Apr 1987 & 8.25 & 18.3 & 0.353 & 0.32 \\
\hline May 1986 & 4.28 & 9.5 & 1.73 & 0.82 \\
\hline \multicolumn{5}{|l|}{ Autumn } \\
\hline Oct 1985 & 5.22 & 15.0 & 0.318 & 0.24 \\
\hline Oct 1986 & 7.11 & 22.9 & 0.304 & 0.35 \\
\hline Oct 1987 & 13.26 & 38.2 & 0.324 & 0.62 \\
\hline
\end{tabular}


All of the clearance rate estimates exceed or are on the high end of rates observed for $C$. pacificus females in the laboratory (typically 5 to $10 \mathrm{ml}$ ind. ${ }^{-1} \mathrm{~h}^{-1}$; e.g. Frost 1972, Landry 1980, Hassett \& Landry 1988). Moreover, our high estimates could indicate that the copepods were doing most of their feeding in patches or depth strata in which food (chlorophyll) concentration was higher than the mean level for the upper $70 \mathrm{~m}$ which was used in computing clearance rates. Ingestion rate estimates are not affected by uncertainties in the spatial relationships of grazers and food and take into account differences in food concentrations during the cruises. We see no evidence by this measure that feeding rates of $C$. pacificus during the winter-spring cruises need to be adjusted by a factor of 3 or so in order to be consistent with the results from autumn (Table 3). In fact, the rate estimates for spring and autumn cruises were similar when mean chlorophyll concentrations were similar (e.g. April 1987 vs October 1985, $1986 \&$ 1987). The highest ingestion estimate (May 1986) corresponds to $1.2 \%$ of body carbon ind ${ }^{-1}$ $\mathrm{h}^{-1}$ for a copepod of $68 \mu \mathrm{g} \mathrm{C}$ (Mullin \& Brooks 1970), or about $28 \%$ of body weight per day assuming continuous feeding. This approaches the maximum ingestion rate of $C$. pacificus females, about $39 \%$ body $\mathrm{C}$ ind. ${ }^{-1}$ $\mathrm{d}^{-1}$ observed at comparable temperature in the laboratory (Frost 1972), and it only includes the contribution of food recognized as phytoplankton. Kleppel et al. (1988) and Small \& Ellis (1992) have indicated that suspension-feeding copepods in the Santa Monica Basin area may derive a significant portion of their nutrition. from detrital and animal carbon. Thus, if the situation for $C$. pacificus females is any indication, multiplying gut pigment contents of zooplankton from the winterspring cruises by a large factor to correct for pigment destruction would lead to unrealistically high estimates of carbon ingested from phytoplankton.
In summary, while shipboard experiments with cultured phytoplankton suggest that a correction for pigment destruction during gut passage should be made for the winter-spring cruises, direct inferences from the water column (i.e. flux profiles of phaeopigments and biogenic silica and gut pigment contents of a dominant zooplankter) argue otherwise. We have chosen not to inflate our gut pigment values by correcting for pigment destruction.

\section{Population grazing estimates}

Grazing rates for the different component populations of mesozooplankton were estimated from the gut pigment contents of Landry et al. (1994) assuming that mean daytime values applied to the period between local sunrise and sunset and mean nighttime values applied between sunset and sunrise. Length of the daylight period varied seasonally from $10.5 \mathrm{~h}$ for the February cruise to $13.6 \mathrm{~h}$ for May. We used a day length of $11.2 \mathrm{~h}$ for all October cruises. Grazing rates for all populations, but particularly copepods and salps, were higher during spring-winter cruises than in the autumn (Fig. 2). Except for February 1988 when salps were abundant, copepods and appendicularians dominated, accounting for at least $80 \%$ of the estimated grazing impact on phytoplankton by the mesozooplankton community.

\section{Community grazing impact}

Mesozooplankton grazing estimates varied seasonally from 1.7 to $7.3 \mathrm{mg}$ chl a $\mathrm{m}^{-2} \mathrm{~d}^{-1}$ (Table 4). All winter-spring estimates (mean $5.8 \mathrm{mg}$ chl a m $\mathrm{m}^{-2} \mathrm{~d}^{-1}$ )
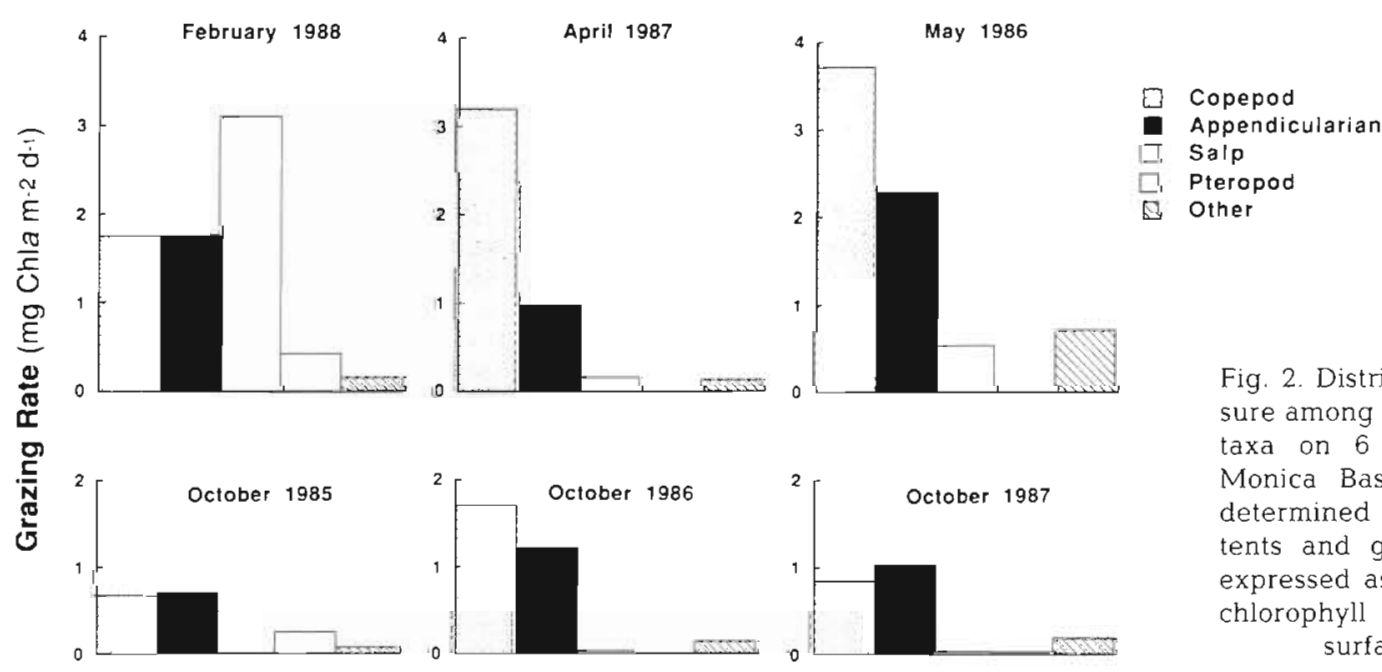

Fig. 2. Distribution of grazing pressure among major mesozooplankton taxa on 6 cruises in the Santa Monica Basin. Grazing rates are determined from gut pigment contents and gut turnover rates and expressed as equivalent weights of chlorophyll a consumed per $\mathrm{m}^{2}$ surface area per day 
were substantially higher than those for the autumn cruises (mean $2.3 \mathrm{mg}$ chl a $\mathrm{m}^{-2} \mathrm{~d}^{-1}$ ). In contrast, grazing as percentage of chlorophyll standing stock cleared per day showed no consistent seasonal difference. On average, mesozooplankton grazing accounted for a loss of $11.7 \%$ of chlorophyll standing stock per day with a 6 cruise range of 6 to $18 \% \mathrm{~d}^{-1}$

Pigment flux from sediment traps below the euphotic zone were highest during the winter-spring cruises

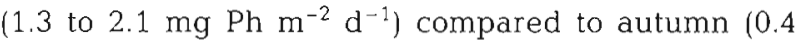
to $1.0 \mathrm{mg} \mathrm{Ph} \mathrm{m}^{-2} \mathrm{~d}^{-1}$ ). The percentage of chlorophyll standing stock lost to phaeopigment flux varied from 1.7 to $5.1 \% \mathrm{~d}^{-1}$ and showed no seasonal trend. The ratio of phaeopigment flux to grazing on chlorophyll was markedly stable for all cruises, varying only between 0.23 and 0.32 . On average, only $27.5 \%$ (SD $3.4 \%$ ) of estimated mesozooplankton grazing appeared in the traps as phaeopigment flux.

Mesozooplankton grazing impacts on phytoplankton carbon were computed from the pigment-based estimates in Table 4 assuming a $C$ : chl a ratio of 50 and compared to measured rates of ${ }^{14} \mathrm{C}$ primary production from Small et al. (1989) in Table 5. Grazing estimates accounted for the utilization of 29 to $44 \%$ (mean $=$ $39 \%$ of primary production on the 3 winter cruises and 16 to $24 \%$ (mean $=19 \%$ ) of primary production on the 3 autumn cruises. If the assimilation efficiency of ingested phytoplankton carbon is assumed to be $70 \%$ with the remaining 30\% going into fecal pellets (Small \& Ellis 1992), the direct grazing pathway from phytoplankton to mesozooplankton can account for 15 to $38 \%$ (mean $=24 \%$ ) of measured carbon flux in winter $/$ spring and 8 to $13 \%$ (mean $=10 \%)$ in autumn (Table 5). These estimates set upper limits to the relative importance of this pathway because they do not allow for any remineralization of sinking fecal matter in the euphotic zone.

\section{DISCUSSION}

\section{Grazing rate estimates}

Estimating grazing rates of mesozooplankton from measurements of their gut pigment contents requires significant assumptions about gut turnover time and

Table 4. Seasonal comparison of chlorophyll-based estimates of mesozooplankton community grazing and pigment flux out of the euphotic zone overlying Santa Monica Basin. Flux rates are the means from 2 or 3 traps immediately below the euphotic zone where phaeopigment ( $\mathrm{Ph}$ ) sedimentation was highest (generally 50 to $60 \mathrm{~m}$, but 40 to $50 \mathrm{~m}$ in February). SD, number of traps given in parentheses. Grazing and flux rates as \% standing stock are both based on depth-integrated chlorophyll to $70 \mathrm{~m}$

\begin{tabular}{|c|c|c|c|c|c|}
\hline \multirow{2}{*}{ Cruise } & \multicolumn{2}{|c|}{ Community grazing } & \multicolumn{2}{|c|}{ Pigment flux } & \multirow{2}{*}{$\frac{\text { Flux }}{\text { Grazing }}$} \\
\hline & $\left(m g \operatorname{chl~m} \mathrm{m}^{-2} \mathrm{~d}^{-1}\right)$ & (\% standing stock) & $\left(\mathrm{mgPh} \mathrm{m}^{-2} \mathrm{~d}^{-1}\right)$ & (\% standing stock) & \\
\hline \multicolumn{6}{|c|}{ Winter-spring } \\
\hline Feb 1988 & 5.76 & 11.3 & $1.74(0.68,2)$ & 3.4 & 0.30 \\
\hline Apr 1987 & 4.47 & 18.1 & $1.74(0.12,2)$ & 5.1 & 0.28 \\
\hline May 1986 & 7.29 & 6.0 & $2.06(0.45,2)$ & 1.7 & 0.28 \\
\hline \multicolumn{6}{|l|}{ Autumn } \\
\hline Oct 1985 & 1.73 & 7.8 & $0.412(0.120,3)$ & 1.9 & 0.24 \\
\hline Oct 1986 & 3.14 & 14.7 & $0.992(0.049,3)$ & 4.7 & 0.32 \\
\hline Oct 1987 & 2.12 & 9.4 & $0.485(0.034,3)$ & 2.1 & 0.23 \\
\hline
\end{tabular}

Table 5. Seasonal comparison of mesozooplankton community grazing on phytoplankton relative to phytoplankton primary productivity in the Santa Monica Basin. Community grazing estimates are the gut pigment rates from Table 4 multiplied by a C:chl ratio of 50. Primary production rates are ${ }^{14} \mathrm{C}$ uptake measurements as reported in Small et al. (1989)

\begin{tabular}{|c|c|c|c|c|c|}
\hline Cruise & $\begin{array}{l}\text { Community grazing } \\
\left(\mathrm{mg} \mathrm{C} \mathrm{m}^{-2} \mathrm{~d}^{-1}\right)\end{array}$ & $\begin{array}{l}\text { Primary production } \\
\qquad\left(\mathrm{mg} \mathrm{C}^{-2} \mathrm{~d}^{-1}\right)\end{array}$ & $\begin{array}{c}\text { Trap flux } \\
\left(\mathrm{mg} \mathrm{C} \mathrm{m}^{-2} \mathrm{~d}^{-1}\right)\end{array}$ & $\frac{\text { Grazing }}{\text { Production }}$ & $\frac{\text { Grazing } \times 0.3}{\text { Flux }}$ \\
\hline \multicolumn{6}{|c|}{ Winter-spring } \\
\hline Feb 1988 & 288 & 660 & 429 & 0.44 & 0.20 \\
\hline Aрг 1987 & 224 & 521 & 445 & 0.43 & 0.15 \\
\hline May 1986 & 364 & 1250 & 284 & 0.29 & 0.38 \\
\hline \multicolumn{6}{|l|}{ Autumn } \\
\hline Oct 1985 & 86 & 531 & 256 & 0.16 & 0.10 \\
\hline Oct 1986 & 157 & 666 & 614 & 0.24 & 0.08 \\
\hline Oct 1987 & 106 & 634 & 237 & 0.17 & 0.13 \\
\hline
\end{tabular}


pigment conservation during the digestive process. Both of these factors are variables, with at least some demonstrated or implied dependency on food concentration (Wang \& Conover 1986, Dagg \& Walser 1987, Penry \& Frost 1990; but see Pasternak \& Drits 1988 , Ellis \& Small 1989), temperature (e.g. Kiørboe et al. 1982, Dagg \& Wyman 1983, Dam \& Peterson 1988), and nutritional history (Head \& Harris 1987, Lopez et al. 1988, Dam et al. 1991, Mayzaud \& Razouls 1992). In addition, there is no a priori reason why they should not vary among species or within the various size classes or developmental stages of a given species. The present study lacks detailed information needed to account for variations in environmental factors within. the water column, for differences in the distributions of grazers relative to environmental variables, or for variations in the dietary histories and requirements among species and groups. We, in fact, take the very simple approach of using the same temperaturecorrected gut turnover rate for all taxa and making no correction for pigment destruction. The implications of these assumptions on our resulting rate estimates are considered below relative to the known capabilities of dominant mesozooplankton taxa in the Santa Monica Basin. Our intent is not to argue that our assumptions are entirely accurate, but rather that they provide reasonable, if not conservative, rate estimates.

Copepods and appendicularians are the dominant mesozooplankton grazers on phytoplankton in the Santa Monica Basin, as judged from the fact that they generally account for 80 to $90 \%$ of community gut pigment content (Landry et al. 1994). As previously noted, our experimental estimates of gut clearance rates, derived mainly from copepods, are in good agreement with the temperature-dependent trends from other studies (Dam \& Peterson 1988). Among the organisms sufficiently numerous to be included in our experiments, we found no substantial differences in gut clearance rates among species, sizes, or developmental stages (see also Tande \& Båmstedt 1985, Hansen et al. 1990, Morales et al. 1990, Peterson et al. 1990). Penry \& Frost (1990) warned that the general approach to estimating gut clearance rates from the decrease in gut pigments of animals in filtered seawater may lead to significant over- or underestimates of true turnover times. Nonetheless, Ellis \& Small (1989) observed good agreement between pigment-based estimates of gut clearance rates and those determined for continuously feeding copepods using tracer methods. Moreover, the gut pigment method generally produces grazing rate estimates for copepods that compare favorably with estimates from independent approaches (e.g Kiørboe et al. 1982, 1985, Head 1986).

We were not able to determine gut clearance rates for appendicularians and other soft-bodied organisms in the present study. However, Alldredge (1981) measured throughput rates for feeding Oikopleura dioica with colored beads and found a minimum time of $8 \mathrm{~min}$. If we extrapolate our measured gut clearance relationship for copepods to the relevant temperature in Alldredge's study $\left(23.5^{\circ} \mathrm{C}\right)$, we would predict a mean throughput time $(11 \mathrm{~min})$ consistent with the minimum time observed. Measured clearance rates for $O$. dioica under in situ conditions in the Gulf of California are also comparable to our rate inferences from gut pigments. For instance, combining Alldredge's (1981) relationship between filtering rate $\left(F, \mathrm{ml}\right.$ ind.$\left.^{-1} \mathrm{~h}^{-1}\right)$ and trunk size $(L, \mathrm{~mm}), \log F=1.621 \log L+0.978$, with observed appendicularian size distributions (Landry et al. 1994) corrected for $10 \%$ shrinkage in formalin, yields mean clearance rate predictions ranging from 2.3 to $4.2 \mathrm{ml}$ ind.$^{-1} \mathrm{~h}^{-1}$ (mean $=3.4 \mathrm{ml}$ ind.$^{-1} \mathrm{~h}^{-1}$ ) for the 5 cruises on which measurements of appendicularian gut pigment content were made. In comparison, our observed daytime gut pigment contents and estimated gut clearance rates give clearance rate estimates varying from 1.3 to $5.2 \mathrm{ml}$ ind. ${ }^{-1} \mathrm{~h}^{-1}$, with a 5 -cruise mean of $2.9 \mathrm{ml} \mathrm{ind}^{-1} \mathrm{~h}^{-1}$. This comparison does not account for differences in environmental temperatures, which would cause the predicted estimates to be about a factor of 2 lower than our observations. The agreement is still quite good, however, since uncertainty in the distributions of appendicularians relative to mean environmental temperatures and food concentrations in our study could account for at least a factor of 2 difference between the regression predictions and our gut pigment estimates.

Of the remaining mesozooplankton taxa in the Santa Monica Basin, only pteropods (October 1985), euphausiids (May 1986), and thaliaceans (February 1988) accounted for $10 \%$ or more of community gut pigment content on any of our cruises. We know of no data from which we can evaluate whether our gut evacuation assumptions for pteropods are appropriate. For euphausiids, Willason \& Cox (1987) estimated $1.08 \mathrm{~h}$ for the gut passage time of Euphausia pacifica adults $\left(12^{\circ} \mathrm{C}\right)$ in the California Current, and Stuart \& Pillar (1990) used estimates of 38 min (temperature unspecified) for adults of E. lucens in the Southern Benguela upwelling region. While these studies would suggest that our grazing rate estimates for euphausiids are exaggerated by the use of the more rapid gut clearance rates of copepods, this problem is likely to be offset, in part, by undersampling of larger euphausiids with our small nets. With regard to thaliaceans, our gut clearance assumptions may overestimate the grazing contribution of large salps according to the direct measurements of Madin \& Cetta (1984) and Madin \& Purcell (1992). For the smaller taxa, however, our grazing rate estimates seem to be reasonable relative 
to the results of other studies. For example, in February 1988 , the period of highest thaliacean abundance, our estimates for the clearance rate of 2 to $5 \mathrm{~mm}$ animals $\left(23.3 \mathrm{ml}\right.$ ind $.^{-1} \mathrm{~h}^{-1}=10.5 \mathrm{ml}$ equ. ind $\left.\mathrm{d}^{-1} \times 2.22 \mathrm{~h}^{-1}\right)$ are in the mid-range of measured rates for comparably sized Thalia democratica $\left(1.5\right.$ to $61.5 \mathrm{ml}$ ind.$\left.^{-1} \mathrm{~h}^{-1}\right)$ and Dolioletta gengenbauri gonozooids ( 2.7 to $69.5 \mathrm{ml} \mathrm{ind} .^{-1} \mathrm{~h}^{-1}$ ) according to the rate-weight and weight-length relationships of Deibel $(1982 a, b)$. Also, for the larger salps which included individuals on the order of $20 \mathrm{~mm}$ in October 1987 and up to $30 \mathrm{~mm}$ in February 1988, our mean rate estimates $\left(82 \mathrm{ml}\right.$ ind..$^{-1} \mathrm{~h}^{-1}$ in Oct. 1987,41 to $55 \mathrm{ml}$ ind. $^{-1} \mathrm{~h}^{-1}$ in Feb. 1988) are similar to Caron et al.'s (1989) experimentally measured rates on comparably sized salps feeding on the small flagellate Isochrysis galbana $117 \mathrm{~mm}$ Cyclosalpa affinis $=54 \mathrm{ml}$ ind $^{-1} \mathrm{~h}^{-1}, 17 \mathrm{~mm}$ Salpa maxima $=104 \mathrm{ml}$ ind $^{-1} \mathrm{~h}^{-1}$, $19 \mathrm{~mm}$ Pegea confederata $=120 \mathrm{ml}$ ind $^{-1} \mathrm{~h}^{-1}$ ). As for appendicularians above, these rate comparisons do not include corrections for differences in environmental temperature $\left(20^{\circ} \mathrm{C}\right.$, Deibel $1982 \mathrm{~b} ; 21$ to $22^{\circ} \mathrm{C}$, Caron et al. 1989).

\section{Pigment destruction}

Pigment loss during zooplankton digestion is a highly variable and poorly understood phenomenon, with reported percentages from the literature ranging from 0 to $99+\%$ (as summarized by Lopez et al. 1988). Nonetheless, our observed seasonal pattern - with high rates $(70 \%)$ of pigment loss in winter-spring and low rates loss $(5 \%)$ in autumn - finds some support in published observations from field and laboratory studies. Head $(1988,1992)$ suggested, for example, that the rate of pigment destruction varied inversely with the degree of starvation and level of feeding activity of field collected copepods. This fits our seasonal trend if we assume that food was most limiting to zooplankton in Santa Monica Basin during autumn. Penry \& Frost (1991) speculated that copepods can achieve a higher rate of net energy gain when acclimated to high food concentration by digesting or absorbing a higher proportion of ingested food. Their experimental results with Calanus pacificus were consistent with this hypothesis. Copepods acclimated to low food concentrations had a very low rate of pigment loss (mean $=8 \%$ for 10 measurements), comparable to what we observed in our autumn experiments. C. pacificus acclimated to high food levels, however, showed higher rates of pigment loss when fed at their acclimation food level ( 24 and $47 \%$ loss for 2 experiments), and the rate of pigment destruction increased by a factor of 2 when they were fed at a lower food concentration.
While our experimental results were consistent with the theory and observations of Penry \& Frost (1991), this does not ensure that they accurately reflected in situ processes. There were many potentially significant differences between environmental conditions on our winter-spring and autumn cruises, including food quantity and quality and species composition of the zooplankton community. Our experimental incubations also excluded the grazing activities of entire classes of grazers (e.g. all gelatinous zooplankton). Differences in food quantity and quality between our laboratory incubations with cultured algae and ambient field conditions may be very important in interpreting our pigment degradation results, since even subtle differences in feeding conditions relative to the zooplankton's feeding history can profoundly influence estimates of pigment loss (e.g. Lopez et al. 1988, Penry \& Frost 1991, Mayzaud \& Razouls 1992). In sum, there are good reasons to question whether the results of our pigment conversion experiments represent the real rates of pigment degradation by zooplankton in Santa Monica Basin or the artificial response of a subset of the grazing community to food conditions to which they are not acclimated. As a consequence, we turn instead to inferences from the phaeopigment: silica ratio, which presumably reflect the net effects of all mesozooplankton grazing processes in the euphotic zone.

Head (1988, 1992; see also Kiørboe \& Tiselius 1987) used the ratio of pigment: silica in fecal material of field collected zooplankton relative to that in available food as an index of pigment destruction. The present study extends this ratio approach to the time- and depthintegrated water column using sediment traps to capture the material exiting the euphotic zone. We make 2 important assumptions in this analysis. First, we assume that biogenic silica and chlorophyll are both consumed by the mesozooplankton community in proportion to their availability as suspended particulates. Second, we assume that the most important pathway through which phaeopigment and silica are lost from the euphotic zone is in the form of mesozooplankton fecal material. If mass sinking of phytoplankton was an important process in the Santa Monica Basin, we would expect to see a high fraction of chlorophyll to phaeopigment in the sediment trap material. In fact, chlorophyll flux was generally on the order of $10 \%$ of the rate for phaeopigment in these short-term trap deployments (Landry et al. 1992), approximately the ratio observed in zooplankton gut contents and fresh fecal material. Conversely, if the bulk of silica and pigments in sediment traps arrived via the slow sinking of very fine particulates, photodegradation of phaeopigments would have resulted in trap material enriched in silica. The similar ratios of $\mathrm{Si}: \mathrm{Ph}$ in the sediment traps 
and the overlying water column are, therefore, consistent with the notion that little of the ingested pigment was lost during gut passage.

Assuming that no ingested chlorophyll is lost to nonfluorescent products during zooplankton gut passage is, at worst, a conservative choice as far as our estimates of community grazing impact are concerned. Clearly, if we applied a factor of 3 to 4 correction to the rate estimates for the winter-spring cruises, community grazing would exceed measured primary production and exaggerate the seasonal trend in the ratio of these rates. Another consequence would be to lower the ratios of pigment-based flux and grazing estimates (Table 4) to substantially less than those observed for autumn. This would seem to be intuitively unreasonable given that larger organisms, which presumably contribute more to particle flux, are relatively more abundant in the zooplankton community during winter-spring.

\section{Grazing-flux relationships}

The present estimates of mesozooplankton grazing (16 to $44 \%$ of phytoplankton production, Table 5) are consistent with the prevailing paradigm that smaller consumers dominate grazing processes in the oceans (Capriulo et al. 1991, Lessard 1991, Landry et al. 1993). The magnitudes of these grazing:production ratios place the Santa Monica Basin intermediate between open ocean and oligotrophic regions, where mesozooplankton directly utilize $20 \%$ or less of phytoplankton production (e.g. Miller et al. 1988, 1991, Morales et al. 1991, Dam et al. 1993, Roman et al. 1993), and richer coastal systems, where mesozooplankton grazing may account for the majority of phytoplankton utilization (e.g. Welschmeyer \& Lorenzen 1985, Landry \& Lorenzen 1989, Bathmann et al. 1990). Moreover, the difference that we observed between the mesozooplankton contribution to grazing for winter-spring $139 \%$ of primary production) and early autumn cruises (19\%) is consistent with the seasonal shift from a diatom-based system in spring to greater flagellate and picoplankton dominance in summer. Roman et al. (1993) noted an even more impressive seasonal shift in mesozooplankton grazing impact in the Western Sargasso Sea - from $1.4 \%$ of primary production during a stable oligotrophic period (August) to $17 \%$ of production during the amnual spring overturn and plankton bloom (March-April).

In the pigment budget model of Welschmeyer \& Lorenzen (1985) both the micro- and macrozooplankton contributions to grazing are estimated using chl a and its degradation products as tracers. The 'macrozooplankton' component of grazing is by definition the proportion of chlorophyll standing stock captured at the base of the euphotic zone as phaeopigment flux into sediment traps. The present results show a consistent factor of 3 to 4 disparity between the grazing estimates of the technically ( $>200 \mu \mathrm{m}$ animals) and functionally defined (producing sinking flux) macrozooplankton (Table 4). As predicted by theory and observed experimentally (Paffenhöfer \& Knowles 1979 , Hofmann et al. 1981), a large fraction of the fecal material produced by animals large enough to be called mesozooplankton sinks too slowly to exit the euphotic zone intact. Even the fecal pellets of relatively large macrocrustaceans have been shown to have a longer residence time in near surface waters than expected when mixing processes are significant (Alldredge et al. 1987). If it is generally true that much of the fecal matter produced by meso- and macrozooplankton grazing behaves with respect to particle flux as if it were produced by organisms $<200 \mu \mathrm{m}$ in size, then the pigment budget analysis will inherently exaggerate the grazing impact of microzooplankton.

As noted in Landry et al. (1994), the mesozooplankton community of Santa Monica Bay is dominated numerically and in terms of gut pigment content by organisms of relatively small size. This would seem. to explain their role as functional microzooplankton. Nonetheless, size structure of the grazing community changes seasonally with no apparent effect on the fraction of the community grazing impact captured as pigment flux in sediment traps (Table 4). It could be that greater physical mixing during the winter and spring months leads to longer residence times of fecal material in surface waters, thus compensating in part for larger mean size of pellet-producing grazers. It may also be that relatively subtle seasonal differences in the species composition of the community lead coincidentally to the observed constancy of the flux: grazing ratios in Table 4. For example, the enhanced role of appendicularian grazing in the autumn could offset reduced size of crustacean consumers if discarded appendicularian houses provided a mechanism for rapid transport of materials through the euphotic zone (e.g. Alldredge 1976, Davoll \& Silver 1986). Zooplankton size is clearly important as a conceptual link between grazing and particulate flux, but it is probably not the whole story.

Despite the accepted notion that zooplankton fecal pellets are an efficient mechanism for rapid transport of particulates through the water column, recognizable fecal pellets are often rare when sediment trap material is examined microscopically (e.g. Pilskaln \& Honjo 1987). In Table 5, we estimated the mesozooplankton contribution to sediment trap flux via direct feeding on phytoplankton using carbon-based estimates of total grazing and an assumed assimilation efficiency of $70 \%$ 
(e.g. Small \& Ellis 1992, Roman et al. 1993). This crude approach accounts for about $24 \%$ of measured trap carbon flux in the winter-spring season and $10 \%$ in the autumn. Such estimates may exaggerate the mesozooplankton contribution to flux to the extent that they do not allow for any recycling of fecal debris in the euphotic zone. However, they could also substantially underestimate total mesozooplankton-related flux because they do not account for feeding on nonpigmented food (i.e. Kleppel et al. 1988, Small \& Ellis 1992). Both of these biases are minimized by using (1) the measured rate of phaeopigment flux into sediment traps as an estimate of mesozooplankton grazed phytoplankton that actually exits the euphotic zone, and (2) the measured $\mathrm{C}: \mathrm{Ph}$ ratio in freshly collected mesozooplankton fecal material as the net effect of all sources of particulate organic matter in diets of mesozooplankton (Downs \& Lorenzen 1985). This latter information is available for zooplankton $>500 \mu \mathrm{m}$ collected during the April 1987, October 1987, and February 1988 cruises in the Santa Monica Basin (Small \& Ellis 1992). For October 1987 the mean C:Ph ratio in fecal pellets produced by large zooplankton was $380 \mathrm{mg} \mathrm{C} \mathrm{mg} \mathrm{Ph}^{-1}$. Multiplying this ratio times the phaeopigment trap flux of $0.485 \mathrm{mg} \mathrm{Ph} \mathrm{m}^{-2} \mathrm{~d}^{-1}$ (Table 4) gives an estimated mesozooplankton-related carbon flux of $184 \mathrm{mg} \mathrm{C} \mathrm{m}^{-2} \mathrm{~d}^{-1}$, about $78 \%$ of measured trap flux (237 $\mathrm{mg} \mathrm{C} \mathrm{m}^{-2} \mathrm{~d}^{-1}$, Table 5). Similarly, if we take Small \& Ellis' (1992) mean C:Ph ratios of 175 and $270 \mathrm{mg} \mathrm{C} \mathrm{mg} \mathrm{Ph}^{-1}$, respectively for the April 1987 and February 1988 cruises, computed carbon fluxes from mesozooplankton grazing (304 and $470 \mathrm{mg} \mathrm{C} \mathrm{m}^{-2}$ $\mathrm{d}^{-1}$, respectively) are $68 \%$ of the measured carbon flux for April and $110 \%$ for February.

Taken at face value, the above calculations suggest that most of the largely nondescript particulate material captured in sediment traps below the euphotic zone could arrive there via processes related to mesozooplankton grazing and fecal transport. The apparent contradiction between this statement and the observed paucity of recognizable fecal pellets (e.g. Urrère \& Knauer 1981, Pilskaln \& Honjo 1987) has several possible explanations. First, the residence time of mesozooplankton fecal pellets in the upper euphotic zone may be sufficiently long for most to degrade to unrecognizable detritus by the time they settle into traps. The factor of 3 to 4 difference between pigment-based grazing estimates of mesozooplankton and pigment fluxes into sediment traps indicates high rates of pigment decay and possible fecal degradation during transport through the water column. Second, our calculations may be biased by using exaggerated $\mathrm{C}: \mathrm{Ph}$ ratios for mesozooplankton feces. For example, the measured rates of fecal pellet carbon production for zooplankton $>500 \mu \mathrm{m}$ in Small \& Ellis (1992) account for an average of only $5.4 \%$ of our trap fluxes for the 3 cruises cited above as compared to the mean $85 \%$ estimate when the fecal $\mathrm{C}: \mathrm{Ph}$ ratios are applied to measured rates of phaeopigment flux. The missing grazers in Small \& Ellis' (1992) fecal pellet incubations, all animals 200 to $500 \mu \mathrm{m}$ and particularly the pelagic tunicates which are unlikely to function normally after net capture, probably have $\mathrm{C}: \mathrm{Ph}$ ratios substantially lower than those of larger crustacean consumers. It should be noted, however, that photodegradation of the phaeopigments in sinking fecal pellets could substantially enrich the $\mathrm{C}: \mathrm{Ph}$ ratio of smaller pellets with a longer residence time in the euphotic zone. Lastly, it may be incorrect to assume that microzooplankton fecal debris is entirely recycled in the euphotic zone (e.g. Welschmeyer \& Lorenzen 1985), particularly if significant grazing occurs in association with aggregated particles or if chance attachment of small fecal debris to macroaggregates (e.g. discarded appendicularian houses) provides a major pathway for pigment flux. Given the present lack of understanding of particle formation and degradation processes in the upper water column, resolving the various pathways for utilization of primary production and their relationships to organic export flux remains a significant and challenging area for future study.

Acknowledgements. This research was supported by U.S. Department of Energy Grants DE-F605-85ER60335 and -88ER60628 and prepared for publication under National Science Foundation Grant OCE-9218152. We gratefully acknowledge the contributions of the captain and crew of the RV 'New Horizon' in the field work and J. Fujimoto in preparing figures and text. Contribution No. 3639 from the School of Ocean and Earth Science and Technology, University of Hawaii at Manoa, Honolulu, HI 96822, USA.

\section{LITERATURE CITED}

Aksnes, D. L., Wassmann, P. (1993). Modeling the significance of zooplankton grazing for export production. Limnol. Oceanogr. 38: 978-985

Alldredge, A. L. (1976). Discarded appendicularian houses as sources of food, surface habitats, and particulate organic matter in planktonic environments. Limnol. Oceanogr. 21: $14-23$

Alldredge, A. L. (1981). The impact of appendicularian grazing on natural food concentration in situ. Limnol. Oceanogr. 26: 247-257

Alldredge, A. L., Gotschalk, C. C., MacIntyre, S. (1987). Evidence for sustained residence of macrocrustacean fecal pellets in surface waters off Southern California. Deep Sea Res. 34: 1641-1652

Baars, M. A., Helling, G. R. (1985). Methodical problems in the measurement of phytoplankton ingestion rate by gut fluorescence. Hydrobiol. Bull. 19: 81-88

Bathmann, U. V., Noji, T. T., von Bodungen, V. (1990). Copepod grazing potential in late winter in the Norwegian Sea - a factor in the control of spring phytoplankton growth? Mar. Ecol. Prog. Ser. 60: 225-233 
Bautista, B.. Harris, R. P. (1992). Copepod gut contents, ingestion rates and grazing impact on phytoplankton in relation to size structure of zooplankton and phytoplankton during a spring bloom. Mar. Ecol. Prog. Ser. 82: 41-50

Capriulo, G. M., Sherr, E. M. Sherr, B. F. (1991). Trophic behaviour and related community feeding activities of heterotrophic manne protists. In: Reid, P. C., Turley, C. M., Burkill, P. H. (eds.) Protozoa and their role in marine processes. Springer-Verlag, New York, p. 219-265

Caron, D. A., Madin, L. P., Cole, J. J. (1989). Composition and degradation of salp fecal pellets: implications for vertical flux in oceanic environments. J. mar. Res. 47: 829-850

Conover, R. J., Durvasula, R., Roy, S., Wang, R. (1986). Probable loss of chlorophyll-derived pigments during passage through the gut of zooplankton, and some of the consequences. Limnol. Oceanogr. 31: 878-887

Dagg, M. J., Walser, W. E. Jr (1987). Ingestion, gut passage, and egestion by the copepod Neocalanus plumchrus in the laboratory and in the subarctic Pacific Ocean. Limnol. Oceanogr. 32: 178-188

Dagg, M. J., Wyman, K. D. (1983). Natural ingestion rates of the copepods Neocalanus plumchrus and $N$. cristatus calculated from gut contents. Mar. Ecol. Prog. Ser. 13: 37-46

Dam, H. G., Peterson, W. T (1988). The effect of temperature on the gut clearance rate constant of planktonic copepods. J. exp. mar. Biol. Ecol. 123: 1-14

Dam, H. G., Peterson, W. T., Okubo, A. (1991). A simple mathematical analysis of the limitations to inferring feeding behavior of zooplankton from gut content. Mar. Ecol. Prog. Ser. 69: 41-45

Dam, H. G., Miller, C. A., Jonasdottir, S. H. (1993). The trophic role of mesozooplankton at $47^{\circ} \mathrm{N}, 20^{\circ} \mathrm{W}$ during the North Atlantic Bloom Experiment. Deep Sea Res. II 40:197-212

Davoll, P. J., Silver, M. W. (1986). Marine snow aggregates: life history sequence and microbial community of abandoned larvacean houses from Monterey Bay, California Mar. Ecol. Prog. Ser. 33: 111-120

Deibel, D. (1982a). Laboratory determined mortality, fecundity and growth rates of Thalia democratica Forskal and Dolioletta gegenbauri Uljanin (Tunicata, Thaliacea) J. Plankton Res. 4: 143-153

Deibel, D. (1982b). Laboratory-measured grazing and ingestion raes of the salp. Thalia democratica Forskal, and the doliolid, Dolioletta gegenbauri UIjanin (Tunicata, Thaliacea). J. Plankton Res. 4: 189-201

Downs, J. N., Lorenzen, C. J. (1985). Carbon:pheopigment ratios of zooplankton fecal pellets as an index of herbivorous feeding. Limnol. Oceanogr. 30: 1024-1036

Ellis, S. G., Small, L. F. (1989). Comparison of gut-evacuation rates of feeding and non-feeding Calanus marshallae. Mar. Biol. 103: 175-181

Emerson, C. W., Roff, J. C. (1987). Implications of fecal pellet size and zooplankton behaviour to estimates of pelagicbenthic carbon flux. Mar. Ecol. Prog. Ser. 35: 251-257

Eppley, R. W., Peterson, B. J. (1979). Particulate organic flux and planktonic new production in the deep ocean. Nature 282: $677-680$

Fasham, M. J. E. (1985). Flow analysis of materials in the marine euphotic zone. Can. Bull. Fish. Aquat. Sci. 213: $139-162$

Frost, B. W. (1972). Effects of size and concentration of food particles on the feeding behavior of the marine planktonic copepod Calanus pacificus. Limnol. Oceanogr. 17: 805-815

Frost, B. W. (1984). Utilization of phytoplankton production in the surface layer. In: Global Ocean Flux Study: proceedings of a workshop. September 10-14, 1984. National Academy Press, Washington, DC, p. 125-135
Furnas, M. J., Hitchcock, G. L., Smayda, T. J. (1976) Nutrientphytoplankton relationships in Narragansett Bay during the 1974 summer bloom. In: Wiley, M. (ed.). Estuarine processes, Vol, 1. Academic Press, New York, p. $118-133$

Hansen, B., Berggreen, U. C., Tande, K. S., Eilertsen, H. C. (1990). Post-bloom grazing by Calanus glacialis, C. finmarchicus and $C$. hyperboreus in the region of the Polar Front, Barents Sea. Mar. Biol. 104: 5-14

Hassett, R. P., Landry, M. R. (1988). Short-term changes in feeding and digestion by the copepod Calanus pacificus. Mar. Biol. 99: 63-74

Head, E. J. H. (1986). Estimation of Arctic copepod grazing rates in vivo and comparison with in vitro methods. Mar. Biol. 92: 371-379

Head, E. J. H. (1988). Copepod feeding behavior and the measurement of grazing rates in vivo and in vitro. Hydrobiologia 167/168: $31-41$

Head, E. J. H. (1992). Gut pigment accumulation and destruction by arctic copepods in vitro and in situ. Mar. Biol. 112 583-592

Head, E. J. H., Harris, L. R. (1987). Copepod feeding patterns before and during a spring bloom in Bedford Basin, Nova Scotia. Mar. Ecol. Prog. Ser. 24: 281-288

Hofmann, E. E., Klinck, J. M., Paffenhöfer, G. (1981). Concentration and vertical fluxes of zooplankton fecal pellets on a continental shelf. Mar. Biol. 61: 327-335

Holm-Hansen, O., Lorenzen, C. J., Holmes, R. W., Strickland J. D. (1965). Fluorometric determination of chlorophyll. J. Cons. int. Explor. Mer 30: 3-15

Kiørboe, T., Tiselius, P. T. (1987). Gut clearance and pigment destruction in a herbivorous copepod, Acartia tonsa, and the determination of in situ grazing rates. J. Plankton Res 9: $525-534$

Kuørboe, T., Mohlenberg, F., Nicolajsen, H. (1982). Ingestion rate and gut clearance in the planktonic copepod Centropages hamatus (Lilljeborg) in relation to food concentration and temperature. Ophelia 21.181-194

Kiorboe, T., Møhlenberg, F., Risggard, H. V (1985). In situ feeding rates of planktonic copepods: a comparison of four methods. J. exp. mar. Biol. Ecol. 88: 67-81

Kleppel, G. S., Frazel, D., Pieper, R. E., Holliday, D. V. (1988) Natural diets of zooplankton off southern California. Mar. Ecol. Prog. Ser. 49: 231-241

Komar, P. D., Morse, A. P., Small, L. F., Fowler, S. W. (1981). An analysis of sinking rates of natural copepod and euphausiid fecal pellets. Limnol. Oceanogr. 26: 172-180

Lampitt, R. S., Noji, T., von Bodungen, B. (1990). What happens to zooplankton faecal pellets? Implications for material flux. Mar. Biol. 104: 15-23

Landry, M. R. (1980). Detection of prey by Calanus pacificus: implications of the first antennae. Limnol. Oceanogr 25 $545-549$

Landry, M. R., Lorenzen, C. J. (1.989). Abundance, distribution, and grazing impact of zooplankton on the Washington Shelf. In: Landry, M. R., Hickey, B. M. (eds.) Coastal oceanography of Washington and Oregon. Elsevier, New York, p. 175-210

Landry, M. R., Peterson, W. K. Andrews, C. C. (1992). Particulate flux in the water column overlying Santa Monica Basin. Prog. Oceanogr. 30: 167-195

Landry, M. R., Peterson, W. K., Fagerness, V. L. (1994). Mesozooplankton grazing in the Southern California Bight. I. Population abundances and gut pigment contents. Mar. Ecol. Prog. Ser 115: 55-71.

Landry, M. R., Monger, B. C., Selph, K. E. (1993). Timedependency of microzooplankton grazing and phyto- 
plankton growth in the subarctic Pacific. Prog. Oceanogr 32: $205-222$

Lessard, E. J. (1991). The trophic role of heterotrophic dinoflagellates in diverse marine environments. Mar microb. Food Webs 5: 49-58

Lopez, M. D. G., Huntley, M. E., Sykes, P. F. (1988). Pigment destruction by Calanus pacificus: impact on the estimation of water column fluxes. J. Plankton Res. 10: 715-734

Mackas, D., Bohrer, R. (1976). Fluorescence analysis of zooplankton gut contents and an investigation of diel feeding patterns. J. exp. mar. Biol. Ecol. 25: 77-85

Madin, L. P. Cetta C. M. (1984). The use of gut fluorescence to estimate grazing by oceanic salps. J. Plankton Res. 6 : $475-492$

Madin, L. P., Purcell, J. E. (1992). Feeding, metabolism, and growth of Cyclosalpa bakeri in the subarctic Pacific. Limnol. Oceanogr. 37: 1236-1251

Mayzaud, P., Razouls, S. (1992). Degradation of gut pigment during feeding by a subantarctic copepod: importance of feeding history and digestive acclimation. Limnol. Oceanogr. 37: 393-404

Michaels, A. F., Silver, M. W. (1988). Primary production, sinking fluxes and the microbial food web. Deep Sea Res. 35: $473-490$

Miller, C. B., Frost, B. W., Wheeler, P. A., Landry, M. R., Welschmeyer, N., Powell, T M. (1991). Ecological dynamics in the subartic Pacific, a possibly iron-limited ecosystem. Limnol. Oceanogr. 36: 1600-1615

Miller, C. B., SUPER Group (1988). Lower trophic level production dynamics in the oceanic subarctic Pacific Ocean. Bull. Ocean Res. Inst. Univ. Tokyo 26: 1-26

Morales, C. E., Bautista, B., Harris, R. P. (1990). Estimates of ingestion in copepod assemblages: gut florescence in relation to body size. In: Barnes, M., Gibson, R. N (eds.) Trophic relationships in the marine environment. Aberdeen University Press, Aberdeen, p. 565-577

Morales, C. E., Bedo, A., Harris, R. P., Tranter, P. R. G. (1991). Grazing of copepod assemblages in the north-east Atlantic: the importance of the small size fraction. J. Plankton Res. 13: $455-472$

Morales, C. E., Harris, R. P., Head, R. N., Tranter, P. R. G. (1993). Copepod grazing in the oceanic northeast Atlantic during a 6 week drifting station: the contribution of size classes and vertical migrants. J. Plankton Res. 15: 185-211

Mullin, M. M., Brooks, E. R. (1970). Production of the planktonic copepod, Calanus helgolandicus. In: Strickland, $J$. D. H. (ed.) The ecology of the plankton off La Jolla, California, in the period April through September, 1967. Univ. Calif. Press, Berkeley, p. 89-103

Paasche, E. (1973). Silicon and the ecology of marine plankton diatoms. 1. Thalassiosira pseudonana (Cyclotella nana) growth in a chemostat with silicate as limiting nutrient. Mar. Biol. 198: 117-126

Pace, M. L., Glasser, J. E., Pomeroy, L. (1984). A simulation analysis of continental shelf food webs. Mar. Biol. 82: 47-63

Paffenhöfer, G., Knowles, S. C. (1979). Ecological implications of fecal pellet size, production and consumption by copepods. J. mar. Res. 37: 35-49

Pasternak, A. F., Drits, A. V (1988). Possible degradation of

This article was submitted to the editor chlorophyll-derived pigments during gut passage of herbivorous copepods. Mar. Ecol. Prog. Ser. 49: 187-190

Peinert, R., von Bodungen, B., Smetacek, V. (1989). Food web structure and loss rates. In: Berger, W. H., Smetacek, V. S., Wefer, G. (eds.) Productivity of the ocean: present and past. Wiley, Chichester, p. 35-48

Penry, D. H., Frost, B. W. (1990). Re-evaluation of the gutfullness (gut fluorescence) method for inferring ingestion rates of suspension-feeding copepods. Limnol. Oceanogr. 35: $1207-1214$

Penry, D. H., Frost, B. W. (1991). Chlorophyll a degradation by Calanus pacificus: dependence on ingestion rate and digestive acclimation to food resources. Limnol. Oceanogr. 36: $147-159$

Peterson, W. T., Painting, S. J., Hutchings, L. (1990). Diel variations in gut pigment content, diel vertical migration and estimates of grazing impact for copepods in the southern Benguela upwelling region in October 1987. J. Plankton Res. 12: 259-281

Pilskaln, C. H., Honjo, S. (1987). The fecal pellet fraction of biogeochemical particle fluxes to the deep sea. Global Biogeochem. Cycles 1: 31-48

Roman, M. R., Dam, H. G., Gauzens, A. L., Napp. J. M. (1993) Zooplankton biomass and grazing at the JGOFS Sargasso Sea time series station. Deep Sea Res. 40: 883-901

Small, L. F., Ellis, S. G. (1992). Fecal carbon production by copepods in Santa Monica Basin: the effects of body size and carnivorous feeding. Prog. Oceanogr. 30: 197-221

Small, L. F., Fowler, S. W., Unlu, M. Y. (1979). Sinking rates of natural copepod fecal pellets. Mar. Biol. 51: 233-241

Small, L. F., Landry, M. R., Eppley, R. W., Azam, F., Carlucci, A. F. (1989). Role of plankton in the carbon and nitrogen budgets of Santa Monica Basin, California. Mar. Ecol. Prog. Ser. 56: $57-74$

Stuart, V., Pillar, S. C. (1990). Diel grazing patterns of all ontogenetic stages of Euphausia lucens and in situ predation rates on copepods in the southern Benguela upwelling region. Mar. Ecol. Prog. Ser. 64: 227-241

Tande, K. S., Båmstedt, U. (1985). Grazing rates of the copepods Calanus glacialis and C. finmarchicus in arctic waters of the Barents Sea. Mar. Biol. 87: 251-258

Tande, K. S., Slagstad, D. (1985). Assimilation efficiency in herbivorous aquatic organisms the potential of the ratio method using ${ }^{14} \mathrm{C}$ and biogenic silica as markers. Limnol. Oceanogr. 30: 1093-1099

Urrére, M. A., Knauer, G. A. (1981). Zooplankton fecal pellet fluxes and vertical transport of particulate organic material in the pelagic environment. J. Plankton Res. 3: 369-387

Wang, R., Conover, R. J (1986). Dynamics of gut pigment in the copepod Temora longicornis and the determination of in situ grazing rates. Limnol. Oceanogr. 31. 867-877

Welschmeyer, N. A., Lorenzen, C. J. (1985). Chlorophyll budgets: zooplankton grazing and phytoplankton growth in a temperate fjord and the Central Pacific Gyres. Limnol. Oceangr. 30: 1-21

Willason, S. W., Cox, J. L. (1987), Diel feeding, laminarinase activity, and phytoplankton consumption by euphausiids. Biol. Oceanogr. 4: 1-24

Manuscript first received: December 27, 1993

Revised version accepted: August 31, 1994 